\title{
Managerial identity work in action: performative narratives and anecdotal stories of innovation
}

Article

Accepted Version

Sergeeva, N. and Green, S. D. (2019) Managerial identity work in action: performative narratives and anecdotal stories of innovation. Construction Management and Economics, 37 (10). pp. 604-623. ISSN 0144-6193 doi:

https://doi.org/10.1080/01446193.2019.1566625 Available at https://centaur.reading.ac.uk/81457/

It is advisable to refer to the publisher's version if you intend to cite from the work. See Guidance on citing.

To link to this article DOI: http://dx.doi.org/10.1080/01446193.2019.1566625

Publisher: Taylor \& Francis

All outputs in CentAUR are protected by Intellectual Property Rights law, including copyright law. Copyright and IPR is retained by the creators or other copyright holders. Terms and conditions for use of this material are defined in the End User Agreement.

www.reading.ac.uk/centaur 
Central Archive at the University of Reading

Reading's research outputs online 


\title{
Managerial identity work in action: performative narratives and
}

\author{
anecdotal stories of innovation
}

Natalya Sergeeva and Stuart D. Green

\begin{abstract}
Innovation is invariably accepted as a central component of construction sector competitiveness. Yet there remains a paucity of empirical research which explores the gap between the way innovation is promoted in the policy discourse and how it is interpreted in practice. We follow the 'narrative turn' in organisation studies to explore the ways in which senior executives in the UK construction sector ascribe themselves with informal roles while advocating the cause of innovation. Empirical data is derived from narrative interviews with 32 senior executives who self-identify as 'innovation champions'. When talking about innovation the respondents were found to oscillate between performative narratives of innovation and more personalised stories derived from their own experience. The narratives were invariably pre-rehearsed often to the point of being monotonous. In contrast, the personalised stories tended to be engaging and emotionally laden. The tendency for senior executives to oscillate between narratives and stories is seen as an important means through which they search for meaning while at the same time legitimising their self-identities as 'innovation champions'. Of particular note is the way in which senior managers self-ascribe themselves with informal roles which are notably at odds with those described in more formalised narratives.
\end{abstract}


Keywords: innovation, narratives, personalised stories, self-identity

\section{Introduction}

The UK construction sector is routinely criticised for its supposed lack of innovation in comparison with other sectors (Egan 1998, Fairclough 2002, Farmer 2016, HM Government, 2013, ICE 2015). There is seemingly a recurring assumption that the construction sector is oldfashioned and in urgent need of modernisation (Fernie et al. 2006). Indeed, the 'fear of not being modern' has been identified as one of the defining discourses of the construction sector (Smiley, 2016). The recurring emphasis on innovation-based competition can be seen to have been naturalised as part of a broader narrative of 'creative destruction' originating with Schumpeter (1976) (first published 1942) (cf. Winch 1998). The key message is that firms must innovate if they are to survive in the global marketplace. Such narratives are habitually promoted by senior managers within the construction sector with the aim of creating a shared acceptance of the need for change. The idea that continuous innovation is an essential component of competitiveness has seemingly become axiomatic within the construction policy domain. The recent Farmer (2016) review of the UK construction sector is especially notable for its quasi-Schumpeterian strapline of 'modernise or die'. On the face of it there is no viable alternative for construction firms other than to commit themselves to the cause of continuous innovation. The accepted sector-level policy narrative of innovation can be referred to as 'performative' in the sense that it is motivated by a desire to improve the performance of the sector. Performativity in this sense follows Lyotard's (1984) definition whereby knowledge is developed and evaluated on the basis of its ability to increase efficiency (Gond et al. 2015, Guérard et al. 2013). This latter tendency is perhaps most obvious in the narrative offered by Rethinking Construction (Egan 1996), but the pursuit of efficiency is a similarly strong defining theme of the Farmer (2016) review. 
In contrast to the above-described policy narrative, the academic literature is much less prone to position the construction sector as a homogeneous entity which is resistant to change. Indeed, the focus of interest in recent years has shifted away from supposed 'attitudinal' barriers towards the way innovation is shaped and constrained by the needs of multiple actors with diverse motivations (Gann 2000, Harty 2005, Sexton and Barrett 2005, Shibeika and Harty 2015, Whyte and Sexton 2011). Winch (2014) describes how projects are delivered by coalitions of permanent organisations which come together in temporary configurations. Hence innovation often takes place at the nexus between permanent organisations and temporary projects. The unit of analysis therefore has to extend beyond temporary project organisations to include the multi-organisational networks within which they are embedded. Dubois and Gadde (2002) further contend that individual projects are only loosely coupled into the overall system, thereby limiting the permeation of sector-level innovation. Others argue that projectbased organisations are themselves inherently innovative in that they continuously (re)create new organisational structures in accordance with the specific needs of each project (Gann and Salter 2000, Hobday 2000). Innovation it seems is rather more nuanced than the construction sector policy narratives would have us believe. Yet there remains an absence of empirical research on how innovation is interpreted by senior executives and the roles they ascribe to themselves in its promotion. If senior executives are indeed pivotal in encouraging the sector to adopt innovation the lack of empirical research of this nature would seem to comprise a significant shortcoming.

Notwithstanding the above it should be emphasised that the theoretical framing of the described research evolved in response to emergent findings. The aim of the research as originally envisaged was to ascertain the ascribed meaning of innovation to those directly tasked with its 
promotion, namely senior executives within construction firms. The primary focus of interest was the way in which they reconciled performative sector-level narratives of innovation with the lessons derived from their own experience. However, the issues of interest to emerge from the data were not entirely as envisaged in the original research design. In this respect the research was abductive in the sense that new theories were mobilised to make sense of emergent findings (cf. Van Maanen et al. 2007). Indeed, as the research progressed, the informal roles which the interviewees ascribed to themselves in the innovation process were seen to be most meaningfully interpreted as 'identity work' (cf. Ibarra and Barbulescu 2010, Ybema et al. 2009).

It must of course be recognised from the outset that 'innovation' is a heavily value-laden term. To adopt a narrative of innovation is to position oneself against the status quo, i.e. to position oneself in favour of 'modernisation'. Such positioning can in itself be meaningfully construed as identity work. It has further long-since been recognised that the field of innovation studies is characterised by 'pro-innovation bias' (Rogers 1995). Practitioners are invariably more willing to talk about innovations which are subsequently accepted as having been successful. It then becomes only a small step to argue that innovations are often only labelled as such retrospectively (Sergeeva 2014). Hence the processes through which selected activities are labelled as 'innovations' can be construed primarily as acts of discursive contestation. And it is through these acts of discursive contestation that the protagonists can be seen to be developing a sense of their own self-identity vis-à-vis the innovation process, and continuously testing this sense of identity against others. It is further important to emphasise that the adopted perspective conceptualises organisations to be in a state of 'perpetual becoming' (cf. Tsoukas and Chia 2002). The focus therefore does not lie on innovation as a reified material commodity, but on the processes of ongoing contestation through which the meaning of innovation is 
continuously contested and ascribed. Such a perspective emphasises activity over substance, and interactive relatedness over discrete individuality (Nayak and Chia 2011, Rescher 1996).

The theoretical position which underpins the described research follows the 'narrative turn' in organisation studies (Frandsen et al. 2017, Rantakari and Vaara 2017). Narratives are defined as unique discursive constructions which provide the essential means of maintaining or reproducing stability and/or promoting or resisting change in and around organisations (Vaara et al. 2016). Although narrative approaches undoubtedly remain relatively unusual within the domain of construction management, there is an increasing number of precedents. Löwstedt and Räisänen's (2012) study of 20 years of change in a Swedish construction company explicitly adopts a narrative perspective, as does the study of Turkish international contracting by Duman et al. (2017). Kanjanabootra and Corbitt (2016) also utilise narrative analysis in their study of the reproduction of knowledge amongst construction professionals. Others who have adopted what might be broadly classified as discursive approaches include: Fernie et al. (2006), Green et al. (2008), Ness (2010), Sherratt (2014) and Sherratt et al. (2013). Of further relevance is Leiringer and Cardellino's (2008) study of the way 'innovation champions' mobilise rhetorical strategies retrospectively to interpret and legitimise the diffusion of innovations.

Discursive arguments such as those cited above notably lack the narrow focus on performativity which characterises the policy literature, i.e. the instrumental aim of improving the performance of the construction sector. However, they are indicative of an increasing acceptance amongst construction management researchers that 'words matter', not least because of their direct material consequences (even if such consequences are rarely deterministic). Green et al. (2008, p. 430) notably construe discourse as a 'body of ideas which 
has significant material effects and consequences as it is mobilised, reproduced and adapted in specific contexts'. Discourse in this sense hence becomes constitutive of reality rather than merely representative. Such an interpretation evokes the enactment view of performativity as advocated by authors such as Callon (1998). Performativity is thereby construed 'as bringing theory into being' whereby (for example) the theory of economics is held to have a direct shaping influence on the reality of how markets work (Gond et al. 2015). A similar argument might feasibly be construed in the case of 'innovation theory'. Hence rather than understanding the literature on innovation as passively describing what happens in a supposed 'external reality', it might likewise be seen to be directly implemented in the shaping of reality. From this perspective, it follows that the very concept of innovation is socially constructed through the language of innovation theory. It is this latter interpretation of performativity which is adopted as the essential starting point for the current paper. However, Brown and Phua (2011) also persuasively argue that language is directly implicated in the social construction of selfidentity. They align in this respect with a particular form of performativity whereby the 'self' is constituted through citation. Gond et al. (2015) trace this interpretation back to the contributions of authors such as Butler (1990) and Derrida (1979). Hence the self-identities of those tasked with leadership become of central importance to any subsequent (or concurrent) shaping of material practices. Yet the current literature is largely silent on the extent to which stories of innovation can be construed as identity work.

\section{The 'narrative turn' in innovation studies}

The 'narrative turn' in innovation studies focuses attention on how the meaning of innovation is socially constructed through the use of stories and/or narratives (Bartel and Garud 2009, Denning 2005, Seidel and O’Mahony 2014). In essence, it is accepted from the outset that 
innovation is a discursive construct subject to multiple interpretations. Bartel and Garud (2009) distinguish between relatively formalised narratives that portray innovation in a structured way through the use of a plot, and 'provisional narratives' which are seen to act as personalised sense-making mechanisms. This distinction relates in part to the 'formal narratives' and 'lived narratives' as presented by Löwstedt and Räisänen (2012).

Narratives are widely accepted as attempts to impose order and are frequently seen as an integral means of organising (Currie and Brown 2003, Vaara et al. 2016, Weick 1979). As such, they tend to be characterised by performative intent; they seek to bring plausibility and coherence to disparate experiences (Brown 2006, Humphreys and Brown 2002). Narratives of innovation can therefore by seen as attempts to persuade, legitimise and guide social actions (Garud 2014). The need for coherence is arguably even more pronounced in project-based organisations in the construction sector, not least because the majority of personnel are likely to be allocated to specific projects on a temporary basis (Hobday 2000). Garud et al. (2011a; 2011b) contend that structured narratives provide the basis for organisational memory by creating a shared history from which employees can draw. Sims (2003) further argues that there is a strong normative expectation that managers should promote a coherent narrative of organisational performance. In essence, this is what managers in leadership roles are supposed to do (Fleming 2001).

Chreim (2005) observes that macro-level narratives of organisational change frequently rely on clichéd labels such as 'innovation', 'ability to change' and 'commitment to employees'. Given the omnipotence of innovation in construction-sector policy narratives, the promotion of innovation as a 'good thing' can be seen as an essential part of the process of seeking external legitimisation. But to a critical eye such narratives of change too easily become repetitive, even 
tending towards the monotonous (cf. Dailey and Browning 2014). Such narratives may even ultimately be counter-productive, serving only to achieve greater degrees of conformity (cf. Frandsen et al. 2017, Geiger and Antonacopoulou 2009, Green 1998).

\section{Performative narratives and personalised stories}

Bartel and Garud's (2009) notion of a 'provisional narrative' can be equated with the stories by means of which individuals ascribe meaning to their past experiences (Boje 2008, Gabriel 2000). Such stories of course are never neutral, objective accounts of pre-determined facts and should not be read as such. Past experience is remembered and interpreted in light of the present, always with at least one eye on a desirable imagined future (Boje 2011, Weick 1979). Hence the argument that activities may only become recognised as innovation retrospectively, and always with a view to serving some future intended purpose (cf. Sergeeva 2014).

It is further important to emphasise again that the 'narrative turn' does not position storytelling as something which is removed from the material realities of organising. The processes of storytelling are seen to be constitutive of the very essence of organising (Gabriel 2000). The literature emphasises the multiplicity of stories and storytellers that characterise the ethereal reality of organisations as they are enacted (Boje 1991, Maclean et al. 2012). Organisations are further portrayed as comprising a series of discursive arenas where a multiplicity of stories are enacted simultaneously; and the constituent stories are invariably multi-authored, fluid and polysemantic (containing multiple meanings). The participation of multiple actors means that the enacted stories inevitably extend beyond personalised sense making to become a means of collective sense making. In the construction sector, many such arenas are routinely positioned within the milieu of individual projects where the responsibility for delivery is shared with 
others. Hence the processes of storytelling invariably involve participants from across the broader 'project coalition'. There is therefore an ongoing dynamic between performative narratives of innovation mobilised at the level of the firm, and anecdotal stories of innovation derived from managers' personal experiences. This interaction is held to be of central importance in the informal roles which managers ascribe to themselves. It is further argued that this process can most meaningfully be understood as identity work.

\section{Stories, roles and self-identities}

Stories undoubtedly play an important role as collective sense-making mechanisms, but they are also concurrently implicated in the social construction of individual identities (Alvesson 2010, Thomas and Davies 2005). Brown and Phua (2011) allude to the way in which identity is of central importance to understanding the dynamics of organising, and to the enactment of leadership in particular. Vaara and Tienari (2011) notably define stories as fragments of organisational discourse that are actively involved in the social construction of identities and interests across time and space. Stories are hence an intrinsic part of the ever-unfolding processes of identity construction; individuals continuously seek to bolster their identities by telling stories, both in the eyes of themselves and others (Alvesson et al. 2008, Brown 2015). Stories are inherently social and emotional in the way people seek empathy and understanding from others when constructing identities (Gabriel 1995, 2000). Hence self-identity often crucially hinges upon the roles which individuals ascribe to themselves during the course of their storytelling (Ashforth 2001, Järventie-Thesleff and Tienari 2016). Brown and Phua (2011) emphasise that informal and self-ascribed roles are forever fluid and temporal rather than fixed. Managers are hence conceptualised as being continuously engaged in complex transitions between self-ascribed informal roles as they seek to navigate between conflicting discursive influences (Ybema et al. 2009). Storytelling is the means through which they 
manage the process of transition, searching continuously for acceptance from those upon whom they depend (Ibarra and Barbulescu 2010).

It follows from the above that managers are constantly constrained in the stories they tell about themselves by the expectations of others (Rhodes and Brown 2005). Fenton and Langley (2011) further allude to the way stories about change frequently draw from both macro-level narratives as well as ad hoc anecdotes derived from past experience. Yet there remains very little empirical evidence regarding the extent to which senior managers in the construction sector draw from these two sources when sustaining their sense of self-identity in respect of innovation. Given the supposed translation role of 'innovation champions' in linking between sector-level narratives of innovation and the day-to-day challenges faced by those working on projects this would seem an important omission.

Of particular relevance to the preceding discussion is Sveningsson and Alvesson's (2003) notion of a 'complex interplay' between organisational discourses, role expectations, narrative self-identity and identity work. In recent years there has undoubtedly been an increased interest in social identity in the construction-related literature, especially amongst those interested in safety (e.g. Andersen et al. 2015, Sherratt et al. 2013). However, the socially constructed identities which managers ascribe to themselves in terms of innovation remains entirely unexplored.

Perhaps the most relevant empirical study from within the construction sector is that provided by Löwstedt and Räisänen (2014). The study is notable for using narrative data to highlight a strong collective self-defining identity amongst managers in a Swedish construction firm. The 
managers concerned were observed to identify themselves as part of an 'in-group' with a strong practical orientation towards action and the materiality of the construction site. This collective identity was in part formed through a shared career path in construction, but crucially it was found to be continually reinforced on a day-to-day basis. Ness (2010) has previously alluded to similarly strong collective identities amongst onsite operatives. This resilient collective pride amongst managers (and operatives) in their ability to derive bespoke solutions to unforeseen problems could easily be equated with a capacity for innovation. Yet innovation on this level is rarely recognised (or valued) in the mainstream construction policy discourse (Ness and Green 2012). Nevertheless, it might reasonably be expected that senior managers would use anecdotal stories derived from their own 'real world' experience as a means of connecting with ‘in-groups’ within construction firms.

\section{Methodological approach}

\section{Empirical focus}

The described empirical research sought to explore the informal roles which senior executives ascribe to themselves in making sense of innovation. Particular emphasis was given to the way they sought to bridge between macro-level performative narratives and their own 'real-world' experience. In essence, the way in which these connections are made is interpreted, at least in part, as identity work. The adopted approach followed the 'narrative turn' by accepting from the outset that 'innovation' is a discursive construct.

Following Löwstedt and Räisänen (2012), the methodology is explicitly aligned with Tsoukas and Chia's (2002) conceptualisation of 'organisational becoming'. Such a perspective emphasises activity over substance, interactive relatedness over discrete individuality, and 
fluidly and evanescence over classificatory stability (Nayak and Chia 2011, Rescher 1996). Hence the empirical focus lay with the fluid and transient processes of 'identifying' rather than with any reified notion of identity as something which is fixed and immutable (cf. Sveningsson and Alvesson 2003). In essence, the research method comprised a series of "narrative interviews' (Hopf 2004, Manning and Cullum-Swan 1994) conducted with senior managers from a range of project-based organisations in the UK construction sector. The adopted sampling strategy concurs with the multi-organisational sampling approach previously adopted by others with a broadly discursive approach to innovation (e.g. Leiringer and Cardellino 2008, Loosemore and Richard 2015).

\section{The participants}

The research participants comprised 32 senior executives from a range of large firms in the UK construction sector. A full list of job titles together with a brief description of the employing organisations is provided in Table 1. The sample included both contractors and consultancy firms, several of which operate globally. Several firms would be best described as UK-based global conglomerates, the largest of which employed in excess of 180,000 employees. Several others employed in excess of 25,000. The smaller firms in the sample usually comprised around 250 employees. The participants were typically in executive management positions. The most common job title was 'Chief Executive Officer (CEO)'. Other job titles included: 'Head of Innovation', 'Innovation Knowledge Manager', 'Business Improvement Manager' and 'R\&D Manager'. The interviewees were offered a promise of confidentiality and hence their identities are protected through the use of pseudonyms. The respondents were initially selected on the basis of self-identification as 'innovation champions' as evidenced by their active participation in Constructing Excellence, a UK-based membership organisation committed to the cause of industry improvement. Constructing Excellence claims to have been delivering best-practice 
and knowledge transfer for more than 20 years. It is one of the most established and seemingly successful construction-related innovation networks in the UK. The mission of Constructing Excellence is described in its 2018 annual report as 'positively disrupting the industry delivery processes to transform performance' (Constructing Excellence, 2018). There is an obvious resonance between Constructing Excellence's stated mission and the Schumpeterian narrative of innovation as an engine of creative destruction. The organisation lists four core activities, one of which relates directly to the showcasing of innovation and best practice. Initial contacts were made through attendance at a series of Constructing Excellence events. Thereafter further contacts beyond Constructing Excellence were made on the basis of personal recommendation by the participants, otherwise construed as 'snowball sampling' (Saunders et al. 2012). The common characteristic was an active interest in the promotion of innovation, not only within their own organisations but also across the sector at large. The narrative interviews were conducted in two phases. The initial phase comprised 21 interviews conducted from 2013 to 2014. A subsequent phase comprised a further 11 narrative interviews conducted from 2015 to 2016. The interviewees all had in excess of ten years' professional experience in the construction sector and had all progressed to the corporate level within their respective organisations. Those from within contracting firms also possessed significant previous linemanagement experience on the level of projects.

\section{INSERT TABLE 1 ABOUT HERE}

It is important to acknowledge that the interviewees were to some extent self-selecting in that they saw themselves as 'innovation champions'. Hence they were willing to talk about 
innovation and how it might be promoted more widely. From the researchers' perspective, it was deemed important that those interviewed should have a broader external credibility as innovation champions. This was seen to be dependent upon their level of seniority, but also on the reputation of the organisations for whom they worked. Several of those interviewed have been involved in sector-level policy debates for some considerable time, and were therefore well-known across the sector - even beyond the networks facilitated by organisations such as Constructing Excellence.

\section{Narrative interviews}

Interviews have long-since been accepted as a valid method for interpretive research within the field of construction management (Dainty et al. 2000). However, there remains a systemic over-reliance on the use of semi-structured interviews. Beyond the specific contributions of Löwstedt and Räisänen $(2012 ; 2014)$ there has to date been little recognition of narrative interviews as a research method amongst construction management researchers. The existing preference for semi-structured interviews is well-illustrated by Loosemore and Richard (2015) who adopted them as a means of exploring the role of clients in 'driving innovation' in the Australian construction sector. Deliberately broad and open-ended questions were presented to 46 influential business leaders and government policy-makers. Loosemore and Richards (2015) set out to access expert opinion on innovation, and to represent it as a broadly monolithic narrative. We would not necessarily question the validity of such contributions, but it is striking how often it is seemingly taken for granted that interviewees are able to provide neutral accounts of a supposed pre-existing reality (Holloway and Jefferson 2008). Qualitative interviews are further often characterised by the problematic assumption that words such as 'innovation' have the same meaning for both interviewer and interviewer. The adopted method of 'narrative interviews' hence notably differs from standard semi-structured interviews both 
in terms of purpose and underlying epistemology. The aim is not to gain access to some sort of fixed external reality, but to gain insights into the discursive processes through which meaning of innovation is socially constructed. The adopted approach was hence consistent with the adopted theoretical perspective whereby organisational reality is conceptualised to be in a state of perpetual becoming (cf. Tsoukas and Chia 2002).

Narrative interviews are specifically designed to encourage respondents to tell stories about their experiences in their own way (Hopf 2004, Manning and Cullum-Swan 1994, Mishler 1991). The interviewee is hence positioned not as a respondent, but as a storyteller (Holloway and Jefferson 2008). The important methodological point is the recognition that such stories in themselves comprise valid data which are worthy of analysis. Of particular importance are 'narrative-generating questions' which encourage the interviewees to describe their own roles in past events (Hopf 2004). The medium of the narrative interview seeks to stimulate people to articulate concepts, to tell stories about themselves, their lived experiences and events. The interview process was sensitive to the feelings and emotions represented within the recited stories, and also to expressions of empathy and humour. The opening 'narrative-generating' question was deliberately generic and open-ended: 'Could you please describe your organisational journey and how you initially became interested in innovation?'. A typical follow-up question thereafter was: 'Could you please tell me more about how you manage innovation in your organisation?'. In contrast to semi-structured interviews, narrative interviews hence place very little reliance on pre-formulated questions. The initial emphasis on the 'organisational journey' was considered important in encouraging the interviewees to look back over time, and to recite stories from their previous experiences. A further common 'narrative generating' prompt was simply to ask how the interviewee understood innovation. This in itself was considered important in opening up the space for innovation to be interpreted 
in different ways. Thereafter the pattern of the narrative interview was that of an interactive conversation (Hermanns 2002). Other than the ill-defined notion of 'innovation' itself, it was seen to be important not to impose externally-derived terminologies on the conversation. For the purposes of consistency, the interviews were conducted by the first-named author on a oneto-one basis.

An important underpinning principle of narrative interviews is that the main narrative should be produced 'independently' by the interviewee (Hopf 2004). However, it must also be recognised that the stories which are recited emerge from the interaction between interviewee and interviewer (Mishler 1991). The meanings which are attributed to innovation and the roles which the interviewees ascribe to themselves are hence at least to some extent co-created within the context of the interview. While the stories offered may engage with reality they also inevitably contain elements of self-projection. In terms of identity work, interviewees can be seen to be continuously testing emergent self-identities. Hence standard concerns about 'bias' do not apply. As alluded to above, the only meaningful form of bias would be for the interviewer to impose an alien language on the interviewee. This may be an issue in those cases where the power differential is balanced in favour of the researcher, but it is much less of an issue when interviewing senior executives. Indeed, following the initial introduction, the interviewees tended to talk freely with little need for prompting. The most common prompts were to ask for examples or further details on the interviewee's own role. The role of the interviewer was often reduced to listening patiently while occasionally affirming her understanding. However, the very presence of an attentive audience inevitably shapes and constrains the content of the interaction. In this sense, the narrative interview is construed as a microcosm of the myriad of encounters which continuously take place within organisations. 
On average, the interviews lasted a little over an hour and were typically held in the interviewees' corporate offices.

\section{Data analysis}

The narrative interviews were transcribed in full, thereby aiding subsequent analysis. The analysis method primarily comprised repeated detailed reading of the transcripts. The analysis was analytically sensitive to the difference between performative narratives and anecdotal stories derived from personal experience. Prior to each interview, reference was made to relevant corporate publicity material especially in terms of the extent to which the organisations publically espoused the benefits of innovation. Although this material did not strictly comprise part of the analysis, it was found advantageous to demonstrate familiarity with this material as a means of establishing credibility with the interviewees. Familiarity also made it easier to detect when interviewees were reciting company policy rather than drawing from their own experience. Although in truth, the distinction was consistently made clear by the interviewees themselves. Particular attention was given to the extent to which references to externally derived narratives were interspersed with personalised stories. The former were identified with the reference to pre-existing published narratives of innovation on the sectoral level (e.g. Egan 1998, Fairclough 2002, Farmer 2016, HM Government 2013, ICE 2015). The analysis was further sensitive to described sequences of events and discursive representations that embody coherence or unity of purpose, otherwise construed as performative intent (cf. Humphreys and Brown 2002).

In contrast to the approach adopted by Loosemore and Richards (2015), equal emphasis in the analysis was given to the anecdotal stories in addition to the more obviously pre-rehearsed 
performative narratives. Such stories were seen as essentially improvised anecdotes relating to the way in which the interviewees made sense of their responses to specific events. They were identified in the interview transcripts by introductory phrases such 'when I was in...', 'I remember the time...', 'for a number of years when I was...', 'back when I worked for...' and 'I think...'. There was no expectation that such anecdotes should exclusively refer to projectlevel experiences, but the analysis was sensitive to the context from which they were derived.

In contrast to the above, references to the formalised mainstream narratives of innovation were coded on the basis of introductory comments such 'It is often argued that...', 'the agenda is...', 'as a leader my job is...', 'we have a strategy in our business...', 'what the industry has to do is...', 'together we are moving forward...'. Reliance was also made on notes taken during the course of the interviews relating to non-verbal signals. Particular attention was given to the way the respondents moved between performative narratives and anecdotal stories rooted in specific projects. The analysis involved multiple readings of the transcripts resulting in several iterations between the entire dataset and emergent findings (cf. Alvesson and Kärreman 2007). This was enacted as a longitudinal process whereby the authors progressed to a common interpretation of the data, or at least a common understanding of the different ways in which it could be interpreted. The analysis was especially sensitive to the informal roles which the interviewees retrospectively ascribed to themselves in the recited stories (cf. Järventie-Thesleff and Tienari 2016). As the research progressed such roles were increasingly construed as identity work in action (cf. Ibarra and Barbulescu 2010, Ybema et al. 2009).

It is of course impossible to represent the richness of the 32 narrative interviews in their entirely. The empirical data presented are therefore directly informed by the theoretical ideas 
discussed previously. Hence the research method is not presented as a neutral means of accessing some sort of supposed external empirical reality, but as a means of illustrating the empirical manifestations of a preconceived set of theoretical ideas. For this reason, the empirical data presented includes relevant references to the literature. This self-awareness of the theoretical shaping of the data is seen to be an essential component of reflexivity. In presenting the empirical findings it is appropriate initially to focus on the extent to which the interviewees reflected the mainstream discourse of innovation as found within the construction sector policy domain. Thereafter, attention is given to the way in which such narratives were supplemented by anecdotal stories derived from the interviewees' personal experiences. Finally, emphasis is given to the described examples of the informal roles to which the interviewees ascribed themselves and the extent to which they could meaningful be construed as identity work.

\section{Empirical findings}

\section{Reflecting the formalised discourses of innovation}

The interviewees' initial default approach was to draw from the formalised discourses of innovation as constituted on the sectoral level, and to emphasise the extent to which these were relevant to their respective firms. The recited narratives invariably positioned innovation as an essential driver of competitiveness:

'People who innovative tend to be open to new ideas, ultimately generating more value for the business. For any business innovation is a good thing.' (Calvin)

Of particular note was the way the rehearsed narratives consistently emphasised innovation as a means of modernisation, thereby reflecting the quasi-Schumpeterian narrative so favoured 
by the construction sector policy discourse. Modernisation was primarily perceived in terms of improving efficiency. But also in terms of adapting to an ever-evolving external landscape. This twin focus is reminiscent of the notion of the 'ambidextrous organisation' as advocated by Duncan (1976).

The strategic intent of many of the rehearsed narratives of innovation was reinforced by references to associated activities such as 'setting the vision', 'developing strategies', 'introducing new language' and ensuring that 'innovation is embedded in the organisational culture'. It was especially common for the interviewees to emphasise the importance of 'understanding the value of innovation'. Other popular strap-lines positioned innovation as 'an essential part of business strategy' or even a 'key organisational value'. Innovation therefore has seemingly become an essential part of a broader narrative of strategic leadership within the selected sample of project-based firms. The tendency to fuse innovation with leadership is wellillustrated in the quotation below:

'For me, innovation leadership is about providing direction and inspiring people. The real innovation leadership is going to be enthusiastic, open-minded, less constrained people who actually realise what is possible. We work together as a team.' (Martin)

Others were less focused on 'providing direction and inspiring people', and rather more focused on innovation as a 'strategic driver':

'There is a growing recognition, certainly in the construction industry that we have to be more alive and more creative. I am saying in my company that this is not about tolerating or accommodating innovation and change, this is about the fact that we have to encourage and make this happen. It is stronger than encouraging. It is insisting that 
we do this - insisting that you innovate or insisting that you question. [This] is sometimes arguably too strong to say. But sometimes you have to take a big hammer. So, I think it is coming. At least a narrative is there, even if the behaviours are not there. There are lots of conversations about innovation.' (Oliver)

The above quotation is especially stark in emphasising that there is no feasible alternative to innovation. A number of interviewees talked very specifically about their role in striving to convince those within their organisations who they perceived to be sceptical or dismissive of the need for innovation. More generally, there was a sense that the narrative of 'continuous innovation' was primarily about securing the commitment of the employees to ongoing processes of change. In this respect the label of 'innovation' is seemingly offered to employees as a plausible means of making sense of their disparate experiences (cf. Chreim 2005, Sergeeva 2014). It could further be argued that the narrative enables employees to adopt a positive selfidentity as supporters of innovation, rather than perceiving themselves as victims of imposed change. Indeed, the narrative that the industry needs to be more innovative translates directly into a shared assumption regarding the need for more 'innovation leaders'.

Several interviewees explicitly allocated roles to a small cadre of people within their organisation who:

'...take the agenda forward, but also help the implementation of the agenda in our business or across projects' (Chris).

This supposedly committed cadre of innovation advocates was frequently positioned within the narrative as some sort of praetorian-type guard whose mission is to protect and promote the cause of innovation. But there was also a recognition that diffusing innovation across projects 
inevitably meant negotiating with others from different firms, thereby at least in part reflecting a recurring theme in the construction-related innovation literature (e.g. Whyte and Sexton 2011, Winch 1998). Building Information Modelling (BIM) was repeatedly cited as an obvious example of innovation as they perceived it, but the interviewees tended to emphasise 'our approach' to the detriment of the more nuanced arguments found in the literature (e.g. Shibeika and Harty 2015). It is of course to be expected that senior executives would find it more important to project a coherent narrative of innovation than to represent the complexities of innovation in practice.

The connotations of performative intent were further strengthened through a variety of different advocated means of achieving compliance, including: 'encouraging', 'convincing' and even in the case of Oliver 'insisting' (see the quotation above). There is of course an obvious paradox in 'insisting' that individuals within the construction sector are 'alive and creative' - especially if the insistence is backed up with a metaphorical 'big hammer'. There is a clear inference here that the required behaviours do not always willingly follow managerial 'encouragement' (at least immediately). Indeed, there was amongst some an expressed need for a more coercive style of management. Although this view was by no means representative, the occasionally expressed tendency towards ensuring compliance resonates with concerns about such narratives becoming counter-productive (cf. Geiger and Antonacopoulou 2009, Green 1998, Frandsen et al. 2017).

Many interviewees notably went to some lengths to emphasise the collective benefit of improving innovation in the sector: 
‘...innovation creates new ideas, it creates job opportunities, brings forward apprentices into new sectors.' (George)

The above line of argument is notable for the way those not supportive of innovation are positioned not only in terms of holding back progress, they are also seemingly denying new job opportunities for aspiring apprentices. The narrative of innovation is hence seemingly targeted directly at those who are positioned as 'dinosaurs' on the basis of their alleged 'oldfashioned attitudes' (cf. Fernie et al. 2006). Of particular note was the consistency of the favoured lexicon of phrases which were consistently linked with the cause of innovation. Phrases such as 'collaboration', 'culture', 'organisational learning' and 'customer responsiveness' were liberally incorporated into a highly flexible but seemingly unchallengeable narrative. Interestingly, the orientation towards continuous innovation was consistently seen to be important for the sector as a whole. There was also a recurring tendency to refer back to the way the firm operated in previous times when the operating environment was (supposedly) much more stable. The 'previous times' were often unspecified, but several interviewees referred specifically to the period prior to Rethinking Construction (Egan 1998).

During the course of the interviews, it frequently became apparent that the above described narrative was heavily pre-rehearsed, i.e. the interviewees were drawing narrative resources from a standardised script. They seemed to be rehearsing them primarily because they felt that this is what was expected of them (cf. Sims 2003). But they did this with few obvious signs of enthusiasm. Indeed, the interviewees only really became animated when reverting to more personalised stories. As each interview progressed, the respondents increasingly departed from the expected script to offer their own insights. Interestingly, the insights offered were often in direct contradiction to the formalised narrative previously advocated. 


\section{Definitional challenges}

One of most common points at which the interviewees stepped down from their performative 'soapboxes' was the point at which they were asked to define innovation. Despite the broad consensus view in favour of innovation, it was striking how little commonality of understanding there was in terms of what innovation means, and especially in terms of how it should be defined. The interviewees were seemingly committed to imploring their employees to adopt innovation without any agreed definition of what it means. Indeed, the interviewees used the label 'innovation' in so many ways as to render it almost meaningless. Innovation was variously positioned as being synonymous with 'change', at other times as the 'successful implementation of a new idea', or even on occasion, the 'successful implementation of a new system'. Very few of the interviewees were willing to talk about unsuccessful innovations, thereby confirming the pro-innovation bias previously observed by Rogers (1995). There was also a perennial blurring between innovation and innovation diffusion such that they were seemingly perceived as blended components of an 'ongoing process':

'When somebody does something innovative we try to turn it into a story or a case study, just to play it back to the organisation. It is probably the most effective change process for us. We have a constant process. That is almost the primary means of managing change.' (Richard)

Such an interpretation of innovation as an ongoing process resonates with the concept of perpetual becoming (Tsoukas and Chia 2002). Innovation from this perspective is not only a discursive construct, but a discursive construct which is subject to continuous contestation.

There was also a recurring lack of clarity in terms of who benefits from innovation, which was at times presented as a route to better profitability. At other times the benefits were seen to 
accrue to end customers, or to those working on the particular project. On other occasions the benefits of innovation were ascribed to even more abstract entities such as 'the process'. Innovation it seems is in the interests of all.

\section{Stepping off the soapbox}

It is clear from the above that the interviewees frequently recited the accepted performative narrative of innovation almost entirely uncritically. However, the mainstream views on offer were often directly challenged once the respondents self-consciously stepped down from their 'soapbox'. This retreat from the pre-rehearsed narrative was often signalled with verbal flags such as 'of course, the reality is much more complex'. Such expressions would serve as convenient segues to more personalised stories. The quotation below provides an example of how interviewees often shifted between the sector-level narrative to describe a more localised approach to innovation in the mode of problem-solving:

'In all honesty, while senior people in our business will know that there are Government targets, I am not sure how much thought in our business goes into what part do we play in meeting those industry targets...So we are not really strategic. It is always we have a problem, we need to fix that problem, and the way to fix that problem maybe to innovate' (Samuel)

The interviewees would then typically recite a number of anecdotal stories on the level of individual projects. They would subsequently return to the accepted performative narrative by means of expressions such as 'of course, the bigger picture is important as emphasised by Egan'. Others for example would emphasise the importance of 'learning the lessons from manufacturing' (cf. Farmer 2016). Such direct references to policy sources provided very 
obvious departure points at which the interviewees aligned themselves once again with the accepted performative narrative of innovation on the sectoral level.

Several interviewees alluded to the idea of the sector possessing a 'leading-edge' at which innovation prospers. This was typically compared with the 'rump' of the industry which was seen to be much harder to influence:

'Something that was striking to me was despite there being a broad consensus over a couple of decades about some of the challenges embracing innovation, it seems to be owned by a group of senior professionals, but beyond making it evident for some projects it does not seem to extend across the industry.' (Martin)

The above quotation is suggestive of the idea that innovation is only recognised as such when it is so-labelled by those who perceive themselves as innovation champions. However, there was little consistency on this point. The preceding quotation was notably juxtaposed with multiple references to bottom-up innovation which occurs 'below the radar'.

A further example of the tendency for the interviewees to descend from their soapbox is provided by the importance attached by the mainstream narrative of "measuring innovation in an objective way'. This seemed to be a standard narrative fragment which was repeatedly rehearsed almost entirely uncritically. 'You can't improve what you can't measure' is arguably one of the most repeated of management clichés, and it was frequently mobilised by the interviewees with direct reference to innovation. But the interviewees equally frequently stood down from their soapboxes to recite more personalised stories about the difficulties of measuring innovation: 
'Innovation is a progression of improvement and bringing in new ideas which other people may have tried. It is a tricky thing to measure because you cannot say 'Oh, we have not seen that ever before' and, therefore, it must be new and innovative'. (Albert)

Others would emphasise the idea of innovation as a 'strategic driver' prior to admitting that in practice their organisation adopted an approach which was much more bottom-up. Innovation in this sense was largely driven by the need to solve problems:

'We are really first steps in the long journey. We innovate all the time, but it is always reactive to a problem rather than planned. We are not really strategic. It is always we have a problem and we need to fix that problem, and the way to fix that problem is maybe to innovate.' (Stephen)

The interviewees ostensibly had no difficulty in living with such contradictions. The narratives that they offered seemed at times to be dependent upon the perceived expectations of the interviewer. There was a tendency initially for the interviewees to draw their narrative resources from the accepted discourse of innovation as represented in the policy domain. However, thereafter they frequently oscillated between the formalised narrative and more personalised stories derived from their own experience. Indeed, the final third of the interview would often be dominated by a succession of highly anecdotal stories. The precise rhythm inevitably varied from case-in-case, in accordance with the subtle interactions between interviewer and interviewee.

On some occasions, the indication of a shift in standpoint would be entirely non-verbal, such as a change in tone or even a subtle shifting of body position. Such a shift would often 
seemingly be initiated by the reaction of the interviewer. For example, an expression of surprise in response to an anecdotal story might immediately cause the interviewee to return to what might be construed as safer ground. It is notable that such non-verbal modes of communication tend to go entirely unreported in the standard mode of semi-structured interviews. As the narrative interviews progressed, it became increasingly evident that the tendency to oscillate between formalised narratives and anecdotal stories could usefully be construed as identity work (cf. Löwstedt and Räisänen 2014, Sveingsson and Alvesson 2003).

\section{Identity work and self-ascribed informal roles}

A good example of identity work 'in flight' is provided by Oliver who was highly critical of the lack of opportunities for younger entrants to the industry:

'I was keen to champion a movement which was recognising the inputs or contributions that people early in their careers can have on the industry. A discussion that I had with myself for twenty years has been: do you have to be old to lead big construction projects? Do you have to have a lot of experience? Why does it appear to be unusual in the construction industry to see younger people in senior positions? I think sometimes it is because the construction industry is quite a conservative, a traditional industry, and it is not one where change is necessary encouraged, or welcomed, or certainly promoted. I always thought that was wrong.' (Oliver)

It is clear from the above that Oliver likes to see himself as a 'maverick' in conflict with (supposed) institutionalised assumptions about the way the industry operates. Once again, there is a sense that the interviewee is promoting a self-image for the purpose of countering the way he may be perceived by others (not least the researcher conducting the interview). Oliver is 
seemingly positioning himself as being in favour of younger entrants into the industry. Yet, it is equally clear that he portrays himself as a lone voice in conflict with the dominant culture.

Oliver also notably alludes to the necessity for employees to gain experience on projects prior to progressing to company-level positions. Arguably, this is also important as a means of gaining acceptance by the 'in-group' (cf. Löwstedt and Räisänen 2014). The interviewee in this case clearly ascribes to himself the informal role of a 'lone enlightened thinker' struggling to operate within the constraints of a conservative industry.

In contrast to the gung-ho leadership narratives previously described, the interviewees often displayed restrained modesty once they had stepped down from their soapboxes:

'I am glad to learn that what we are doing has been recognised. I am not recognising myself as an innovation leader. I think I am trying to do what is the right thing here. If it is good enough and strong enough it will survive our legacy. Another organisation will decide to sort of adopt it.' (George)

The self-ascribed role here might be summarised as 'honest John' - striving to exercise common sense and to do the 'right thing'. Interestingly, such expressions of restrained modesty were occasionally interspersed with contradictory statements of self-aggrandisement:

'I get very bored of doing the same thing day and day after. I enjoy doing things differently, not for the sake of change, but I enjoy stretching myself, pushing myself. If we talk about me, not being arrogant, I have driven a lot of things in our organisation. If you make a chart when these things happen, it would happen when I am bored.' (Alexander) 
The self-ascribed central role in the above quotation notably morphs into that of 'action man' whereby the most important thing is to make things happen. This would seem to concur with one of identified characteristics of the 'in-group' within the Swedish construction firm as described by Löwstedt and Räisänen (2014). Striking the appropriate balance between informal roles such as 'honest John' and 'action man' would seem to be of central importance to those who occupy such leadership roles, and is hence suggestive of continuously contested selfidentities. Female executives might likewise self-ascribe to similarly contested identities of 'honest Jane' and 'action woman'.

\section{Telling a good story}

The interviewees were undoubtedly adept at telling engaging stories about their roles in the innovation process. The ability to 'tell a good story' is arguably an essential characteristic of successful leaders. The interviews revealed a strong self-awareness amongst the interviewees of the importance of storytelling as a managerial function. A typical anecdotal story was recited by Brian:

"I was in Poland this week, and we had an opportunity to think about quite complex circumstances. A couple of my colleagues said: 'programme management' is a solution to this problem. I said I am not convinced. What I would like to do is to engage the client in a discussion regarding the nature of the problem. Let's tell that client a few stories about some of the things we have done in similar situations. They will never be the same because they are always different. Let's tell that client a story, whether it is about road business, 
Olympics, and tell some stories where we have done things in a quite creative, 'innovative' way, where he might go: 'That is really relevant to my business."

What is striking in the above is the self-awareness of the interviewee of the importance of using bespoke narratives to influence clients on specific projects. He also talked about encouraging others within the firm to use narratives for the purposes of persuading clients towards desired outcomes. The above quotation also illustrates that the narratives which prevail on different projects are not necessarily expected to be the same. The self-awareness of the importance of storytelling was not unusual, and was by no means limited to projecting the identity of the organisation externally. One interviewee explicitly referred to the need to construct a more consistent language around innovation:

'What I would like to do is to sort of pull through in a more explicit way a strategy for innovation which people understand; there is a vocabulary and language around people when they talk about innovation. If you went to interview 10-15 people in our business and ask about innovation. You will get 10-15 different answers. So, what I have got to do with my leadership team is perhaps bring some consistency in what it means to our business in a more explicit way. Once we do it, we can then overlay that in our current strategy, so that it becomes more in a DNA of an organisation.' (Charles)

The interviewee hence not only recognises that different organisational members will have different interpretations of innovation, but also ascribes himself with the role of articulating a more consistent strategic narrative. Hence, the role of 'organisational storyteller' morphs into that of 'organisational scriptwriter' with an implied direct performative intent. 
The quotation above from Charles suggests that on occasion personalised stories can hinge around an individual's role in the development of formalised narratives. As an aside, the metaphor of an organisation's 'DNA' was mobilised by several interviewees with specific reference to ensuring that innovation is accepted as normal business. However, this does once again raise the question of whether adherence to a more consistent script across the organisation risks stifling innovation rather than encouraging it. It also rather contradicts Brian's implicit recognition that different projects invariably need different narratives of innovation which are designed to appeal to different clients. The paradox is that senior management is committed to the encouragement of innovation, but only innovation which serves a broadly pre-defined agenda. The difficulty lies in making this agenda relevant to those whose experiences vary so much from project to project.

As previously suggested, the informal 'off-soapbox' stories about innovation tended to become more anecdotal - and personalised - as each interview progressed. The anecdotal stories tended to be situated in very specific contexts, usually on the level of individual projects, but also on occasion relating to broader life experiences. It was further notable that the shared stories were frequently not directly related to the topic of 'innovation' as commonly understood. More often than not the interviewees' stories were centred on their own personal identities and beliefs, and their day-to-day engagement in the micro-dynamics of individual projects. The stories offered were frequently engaging and entertaining in nature, very often encompassing no small degree of emotion. Many of the stories were based around recollections of previous projects. For example, Harry shared a story about a previous role in the construction of a new academic building. The story centred on his personal role in generating interactions between the different building occupants (who otherwise seemingly rarely communicated). The project brief had 
apparently challenged the project team to design a building with a high degree of flexibility. The resultant design configured the space into what was described as a 'doughnut' arrangement. Great emphasis was apparently placed on an internal honeycomb arrangement together with the use of an atrium for the purposes of extracting warm air and hence improving ventilation. The CEO told this story with significant affection and was undoubtedly very proud of the finished 'lovely' building. He specifically remembered being impressed by the lead architect asking permission to bring his family to see the building. The story as recited emphasised that the CEO had thought the architect was talking only about his partner and their children. The punchline was then delivered with great delight and dramatic effect - the architect apparently not only arrived with his children, but with his entire extended family including nephews and nieces [laughs]. Stories of this nature are clearly memorable and are rendered more so because of their implicit humour.

The above story portrays a very human image of construction and captures the pride which professionals invariably take in their work. Of particular note is that the supposed innovation itself is not central to the story - a much stronger emphasis is given to the obvious pride that the architect had in his own contribution. However, it is striking that the story strays across organisational boundaries to focus on an actor who worked for a separate firm. The heartfelt message is that individuals involved in projects intrinsically value the contributions which they make. This is not a message about cost efficiency, nor is it a message about monetary reward for a profitable project. It is a message that colleagues who take a professional pride in what they do are those who receive recognition; and the subtext is that those who portray pride in projects will attract similar attention in the future. The story picks up the theme of pride from the past and portrays it into the future. This same theme was echoed across many of the interviews. Such anecdotal stories were frequently linked to taking in pride in the job. The self- 
ascribed role is that of 'portrayer of pride', and the implication is that this is an important function of leadership.

There was also ample evidence of the use of stories as a means of connecting 'lived moments' in the past with future challenges. Such stories were invariably highly anecdotal, but they were also thoughtful and representative of a tendency to reflect on personal experiences. Elizabeth, the female CEO, was especially prone to share stories from her family life. However, her stories were also consistently notable for the emphasis given to learning from past mistakes. The selfascribed role would seem to be that of 'reflective practitioner', and the message to others is to reflect on the mistakes of the past with a view to avoiding them in the future. But the message was mediated by an explicit recognition that individuals have responsibilities beyond the workplace, including responsibilities to their own family. The self-ascribed role perhaps extends beyond reflective practitioner to that of 'empathetic reflective practitioner'. Yet there was also a strong concurrent emphasis on the need to accept 'commercial realities'. As with so many other stories which were shared, the messages were not entirely consistent. The message regarding the need to share best practice is of course central to the accepted sector-level improvement narrative. But the more personalised stories consistently tended to challenge such top-down prescriptions and the extent to which they are useful in dealing with lived experiences. Such contradictions were by no means uncommon.

\section{Discussion}

\section{Talking about innovation}

At its most prosaic, the research described above confirms the contention that senior executives in the construction sector like to talk about innovation. The initial invitation to talk about their 
'innovation journey' was certainly successful in encouraging the interviewees to share their views. The interviewees seemingly recited the pre-rehearsed performative narratives of innovation because this is what they felt was expected of them (Sims 2003), but this could equally be construed as identity work (Sveningsson and Alvesson 2003). Certainly the interviewees consistently strived to present themselves as active promoters of innovation, thereby continually reinforcing their own sense of self-identity. Several of the interviewees were aware of the importance of projecting a coherent narrative as a means of providing the organisation with a strong sense of direction. This interpretation would seem to align strongly with the notion of a 'leadership narrative' as described by Fleming (2001). It would further seem to support the contention that narratives comprise an integral means of organising (Currie and Brown 2003). There is perhaps cause for reflection here on the part of those who routinely use interviews as a means of accessing a supposedly objective reality. The perennial difficulty that the interviewees had in defining innovation also serves to reinforce the contention that innovation is more meaningfully understood as a discursive construct.

Although the interviewees were specifically asked about their 'innovation journey', the narratives which they shared in response tended to blur the notion of innovation into a broader malleable 'agenda for change'. The mobilised narratives would also slip seamlessly into talking about 'business improvement', 'customer responsiveness', 'improving efficiency' and a whole host of such terms seemingly derived from the discourse of enterprise (du Gay and Salaman 1992, Green et al. 2008). It is further notable that the performative narratives offered frequently tended towards the bland and monotonous (cf. Dailey and Browning 2014, Vaara et al. 2016). Indeed, the interviewees themselves often seemed to become bored with these generic narratives. They became noticeably more animated once they stepped off the 'soapbox' to recite their own anecdotal stories. The personalised stories were invariably communicated with 
an enthusiasm which had previously been lacking, and often with no small amount of humour and empathy. The respondents noticeably became more willing to share such anecdotes as each interview progressed, arguably as a consequence of becoming more relaxed, and perhaps more trusting of the interviewer (aka the 'audience').

\section{Oscillating between performative narratives and anecdotal stories}

The observed tendency to oscillate between repeated macro-level performative narratives and micro-level stories constructed around personal experiences relates in part to previous findings (e.g. Ibarra and Barbulescu 2010, Vaara et al. 2016). The propensity to oscillate between performative narratives and anecdotal stories can also be construed as an identity struggle (Sveningsson and Alvesson 2003). Alignment with externally-derived performative narratives would routinely reinforce the self-identities of the interviewees as 'agents of change'. Participation in external networks such as Constructing Excellence would further strengthen their allegiance to the cause of industry change. At risk of conjecture, it could be that the accepted narrative of the construction sector as being adversarial and slow to change comprises on ongoing exercise in identity work on the part of those who advocate such arguments.

Notwithstanding their difficulties in defining innovation, the interviewees were consistent in emphasising its importance, and in positioning such narratives against a supposed resistance to change amongst (some) employees. However, it is understandable that senior executives would be reluctant to perceive themselves as being little more than passive conduits for externallygenerated messages. Such a perception would contribute little towards a positive self-identity. Indeed, many of the anecdotal stories derived from their personal experiences were often in direct contradiction to the narratives they seemingly felt obliged to rehearse. The process of 
oscillating between generic narratives and personalised stories could arguably be understood as a means of sense making of which identity work is a key component (Weick 1979).

\section{Self-ascribed informal roles}

The stories derived from personal experiences were notable for the creation of informal roles linked to the managers' self-identities (cf. Ibarra and Barbulescu 2010, Järventie-Thesleff and Tienari 2016). The roles described were consistently informal, and hence say more about how the interviewees see themselves than they do about their respective organisations per se. Yet the senior executives interviewed not only told stories, they were also good at telling stories. The informal roles described were invariably very vivid, and were used not only to portray how the interviewees perceived the past, but also to provide prototypes for what they saw to be important in the future (Boje 2011). There is little reason to think that the roles were in any way fixed or replicable; continuous fluidity and transition would be the default expectation of 'perpetual becoming' (cf. Tsoukas and Chia 2002). Hence the stories offered are best understood as fleeting windows into the process through which individuals create a 'sense-ofself' together with tentative modus operandi for the future (cf. Alvesson 2010). Self-ascribed roles derived from lived experience provide templates for future modes of organising, and as such may well have direct material consequences. Stories are not just about the past, they are also about shaping the future.

On occasion, the roles were very simple, perhaps even tending towards the simplistic, e.g. 'honest John', 'action man'. On other occasions, the roles described were more sophisticated, i.e. 'portrayer of pride', 'lone enlightened thinker', 'organisational scriptwriter', 'empathetic reflective practitioner'. Many of these latter roles are in contrast to the oft-quoted supposed 
stereotypes of mangers in the construction sector. But it would be misrepresentative to suggest that the interviewees only portrayed themselves as enacting a single role. The roles described were by no means fixed, and were very often positioned as being in competition with each other (even in the course of the same story). At times there was a sense that the interviewees were using the interviews as a means of testing emergent self-identities against a captive audience. In this respect, each narrative interview comprised a microcosm of the day-to-day discursive nature of identity work. It has already been observed how often the personalised stories looked back to the interviewees' previous experiences. But it is evident that the stories offered were far from neutral in their interpretation of past events; and they were clearly recited in such a way as to highlight the contribution of the narrator. Here again, it is easy to relate to the claim that past experiences are recalled and re-shaped to support a subsequent emergent self-identity (Alvesson 2010).

\section{Oscillation as a means of searching for meaning}

There is little reason to believe that the tendency of stories to contradict the accepted narratives is unique to the concept of innovation, or indeed to project-based organisations within the construction sector. It could further be argued that such processes of contestation are central to the discursive social construction of meaning, and hence a primary mechanism through which such narratives are renewed and reconfigured. Narratives of course often become popular as a direct result of the essential ambiguity of their constituent terms (Abrahamson 1991). Hence the very notion of 'innovation' remains popular for the very reason that it is subject to multiple interpretation. The stories recited would seem to be indicative of the interviewees' perennial search for meaning when faced with contradictions between the narratives they felt obliged to promote, and lessons derived of their own experiences. Organisations are of course full of such 
contradictions, and narration and storytelling are essential means of dealing with them (Boje 2011, Gabriel 1995, 2000).

\section{Performativity}

It is finally appropriate to return to the issue of performativity. Although the interviewees frequently rehearsed performative narratives derived from the policy discourse they notably did not accept the narrow mantra of efficiency entirely uncritically. However, there was a recognition amongst many that 'words matter'. This was evidenced by a consistent selfawareness of the importance of projecting a consistent narrative of improvement. Of particular note are those who advocated the use of bespoke narratives for the purposes of influencing particular clients. There was undoubtedly a level of sophistication amongst the interviewed senior executives which goes beyond any narrow Lyotardian focus on the need to improve performance. The interviewees were invariably highly reflective and were by no means constrained by constricted notions of 'instrumental rationality'. The anecdotal stories which they recited notably demonstrated a strong orientation towards engaging with the reality of 'real world' problems, rather than confining themselves to esoteric rhetoric.

With reference to the second meaning of performativity in terms of 'bringing theory into being' as advocated by Callon (1998), caution is necessary in what can reasonably be inferred from the data. The elicited narratives are perhaps suggestive that the perennial sector-level quasiSchumpeterian narrative of innovation plays an active role in shaping the reality of the construction sector. Yet, it is important to emphasise that performativity in this sense has categorically not been demonstrated empirically. Indeed, it is difficult to imagine how such a contention could ever be demonstrated empirically. In essence, 'bringing theory into being' 
remains a theoretical idea. However, it is clear that the discourse of innovation unfolds in complex ways which counter any simplistic tendency towards determinism. As already noted, the discourse of innovation plays out in combination with other discourses which inevitably interact and combine in complex and unpredictable ways. It must also be emphasised that the theoretical orientation towards understanding organisations as entities which are in a state of perpetual becoming sits in tension with any notion of tracing causality over time (cf. Nayak and Chia 2011).

Notwithstanding the above caveat, the data contains extensive evidence to support the contention that the language of innovation is directly implicated in the social construction of self-identity. The narrative interviews in themselves provided excellent examples of identity work in action. However, Brown and Phua's (2011) observation that informal and self-ascribed roles are forever fluid and temporal rather than fixed remains highly pertinent. The interviewees invariably had meetings to go to immediately following the narrative interview. Such meetings could similarly be construed as narrative encounters whereby the interviewees would continue to project tentative self-identities to different audiences, tailoring further adjustments in respond to feedback. Such is the ubiquitous nature of identity work.

\section{Conclusion}

The described study contributes to an emerging theme of discursive research relating to innovation in the construction sector. In contrast to the positivism which underpins the majority of previous studies, we have followed the 'narrative turn' in positioning innovation as a discursive construct subject to continuous contestation. The findings shed important light on an identified research gap relating to the self-identities to which senior executives self-ascribe 
as a means of making sense of the complex settings within which they operate. A rhetorical commitment to innovation is seen to be of central importance to their sense of self-identity as they seek continuously to position themselves as 'agents of change'. The recited performative narratives of innovation can also be read as attempts to bring plausibility and coherence to a broad diversity of experiences throughout their respective organisations. Yet senior executives also face the challenge of connecting with their lived experiences.

The research has further highlighted the ways in which senior executives seek more nuanced self-identities beyond that of being relatively passive advocates of an often monotonous sectorlevel narrative. Hence their consistent use of anecdotal stories as a means of connecting with those working at the project level. The narrative interviews conducted during the course of the research can be seen as microcosms of the innumerable encounters which continuously take place across organisations. These encounters provide the context for the ongoing discursive contestation of innovation as organisational actors continuously test emergent self-identities against different audiences. It is contended that these same discursive processes are directly implicated in the determination of which activities are held to be 'innovative' (and which are not). The empirical research suggests that what counts as innovation is inexorably linked to the self-identities of those involved. As such, the processes through which these identities are contested are as much about the future as they are about the past.

It is considered significant that so many of the personalised stories were rooted in the context of specific construction projects. This was especially true for those senior executives within the contracting firms, thereby reinforcing previous findings regarding the importance of 'ingroups' orientated towards practical action and the materiality of the construction site. The unique contribution of the current article lies in demonstrating the way in which senior 
executives oscillate between performative narratives of innovation and anecdotal stories derived from their own experiences. This process of oscillation is seen to be of central importance to the ongoing processes of sense making, not least those which relate to social construction of self-identity.

Given the highly contextualised nature of the stories which were shared, it would be naïve to attempt to generalise beyond the individual encounters within which the stories were generated. With a different interviewer, on a different day, the interviewees may well have recited very different stories. The important finding therefore does not lie in the content of the stories, but in the way in which the stories provide insights into 'identity work in action'. Nevertheless, the observed process of oscillation opens up a new understanding of the way in which executives bridge between the level of the organisation and that of relatively discrete self-contained projects. The linking of innovation as a discursive construct to the formulation of the selfidentities of senior executives in construction firms is held to be an original contribution to the field, both in terms of its theoretical conceptualisation and its empirical findings.

\section{References}

Abrahamson, E., 1991. Management fads and fashions: The diffusion and rejection of innovations. Academy of Management Review, 16(3), 586-612.

Alvesson, M., 2010. Self-doubters, strugglers, storytellers, surfers and others: Images of selfidentities in organization studies. Human Relations, 63(2), 193-217.

Alvesson, M., Ashcraft, K. L. and Thomas, R., 2008. Identity matters: Reflection on the construction of identity scholarship in organization studies. Organization, 15(1), 5-28. 
Alvesson, M. and Kärreman, D., 2007. Constructing mystery: Empirical matters in theory development. Academy of Management Review, 32(4), 1265-1281.

Andersen, L.P., Karlsen, I.L., Kines, P., Joensson, T. and Nielsen, K.J., 2015. Social identity in the construction industry: implications for safety perception and behaviour. Construction Management and Economics, 33(8), 640-52.

Ashforth B.E., 2001. Role transition in organizational life: An identity-based perspective. Mahmah: Lawrence Erlbaum Associates.

Bartel, C.A. and Garud, R., 2009. The role of narratives in sustaining organizational innovation. Organization Science, 20(1), 107-117.

Boje, D.M., 1991. The storytelling organization: A study of storytelling performance in an office supply firm. Administrative Science Quarterly, 36(1), 106-126.

Boje, D.M., 2008. Storytelling organizations. London: Sage Publications.

Boje, D.M., 2011. Storytelling and the future of organizations: An antenarrative handbook. Abingdon: Taylor \& Francis.

Brown, A.D, 2006. A narrative approach to collective identities. Journal of Management Studies, 43(4), 731-753.

Brown, A.D., 2015. Identities and identity work in organizations. International Journal of Management Reviews, 17(1), 20-40.

Brown, A.D. and Phua, F.T.T., 2011. Subjectively construed identities and discourse: towards a research agenda for construction management. Construction Management and Economics, 29(1), 83-95.

Butler, J., 1990. Gender trouble: Feminism and the subversion of identity. NE: Routledge.

Callon, M., 1998. The laws of the markets. Oxford: Blackwell.

Chreim, S., 2005. The continuity-change duality in narrative texts of organizational identity. Journal of Management Studies, 42(3), 567-593. 
Constructing Excellence, 2018. Constructing Excellence Annual Report (http://constructingexcellence.org.uk/wp-content/uploads/2017/12/Constructingexcellence-annual-report6.pdf) [Accessed $5^{\text {th }}$ March 2018].

Currie, G. and Brown, A.D., 2003. A narratological approach to understanding processes of organizing in a UK hospital. Human Relations, 56(5), 563-586.

Dailey, S.L. and Browning, L., 2014. Retelling stories in organizations: Understanding the functions of narrative repetition. Academy of Management Review, 39(1), 22-43.

Dainty, A.R. J., Bagilhole, B.M. and Neale, R.H., 2000. Computer aided analysis of qualitative data in construction management research. Building Research \& Information, 28(4), 226-33.

Denning, S., 2005. Transformational innovation: A journey by narrative. Strategy \& Leadership, 33(3), 11-16.

Derrida, J., 1979. Signature event context. Glyph, 1, 172-197.

du Gay, P. and Salaman, G., 1992. The culture of the customer. Journal of Management Studies, 29(5), 615-633.

Dubois, A. and Gadde, L.E., 2002. The construction industry as a loosely coupled system: implications for productivity and innovation. Construction Management and Economics, 20(7), 621-31.

Duman, D.U., Green, S.D. and Larsen, G.D., 2017. Competitive strategy and the role of narrative infrastructure: the case of Turkish contractors. In: P.W. Chan and C.J. Neilson ed. Proc. 33rd Annual ARCOM conference, 4-6 September 2017. Fitzwilliam College, Cambridge: Association of Researchers in Construction Management, 622-631.

Duncan, R., 1976. The ambidextrous organization: Designing dual structures for innovation. In: R.H. Killman, L.R. Pondy and D. Sleven ed. The Management of Organization, NY: North Holland, 167-188 
Egan, J., 1998. Rethinking construction. London: Department of the Environment, Transport and Regions (DETR).

Fairclough, J., 2002. Rethinking construction innovation and research: A review of government $R \& D$ policies and practices. London: Department of Trade and Industry (DTI).

Farmer, M., 2016. The Farmer review of UK construction labour model: Modernise or die. London: Construction Leadership Council.

Fenton, C. and Langley, A., 2011. Strategy as practice and the narrative turn. Organization Studies, 32(9), 1171-1196.

Fernie, S., Leiringer, R. and Thorpe, T., 2006. Change in construction: A critical perspective. Building Research and Information, 34(2), 91-103.

Fleming, D., 2001. Narrative leadership: Using the power of stories. Strategy \& Leadership, 29(4), 26-34.

Frandsen, S., Kuhn, T. and Lundholt, W., 2017. Counter-narratives and organization. NY and London: Routledge.

Gabriel, Y., 1995. The unmanaged organization: Stories, fantasies and subjectivity. Organization Studies, 16(3), 477-501.

Gabriel, Y., 2000. Storytelling in organizations: Facts, fictions, and fantasies. Oxford: Oxford University Press.

Garud, R., 2014. Contextualizing entrepreneurial innovation: A narrative perspective. Research Policy, 43(7), 1177-1188.

Gann, D.M., 2000. Building innovation: Complex constructs in a changing world. London: Thomas Telford.

Gann, D. and Salter, A., 2000. Innovation in project-based, service-enhanced firms: the construction of complex products and systems. Research Policy, 29(7-8), 955-972. 
Garud, R., Dunbar, R. L. M. and Bartel, C.A., 2011a. Dealing with unusual experiences: A narrative perspective on organizational learning. Organization Science, 22(3), 587-601.

Garud, R., Gehman, J. and Kumaraswamy, A., 2011b. Complexity arrangements for sustained innovation: Lessons from 3M corporation. Organization Studies, 32(6), 737-767.

Geiger, D. and Antonacopoulou, E., 2009. Narratives and organizational dynamics: exploring blind spots and organizational inertia. Journal of Applied Behavioural Science, 45(3), $411-436$.

Gond, J.-P., Cabantous, L., Harding, N. and Learmonth, M., 2016. What do we mean by performativity in organizational and management theory? The uses and abuses of performativity. International Journal of Management Review, 18(4), 440-463.

Green, S.D., 1998. The technocratic totalitarianism of construction process improvement: a critical perspective. Engineering, Construction and Architectural Management, 5(4), $376-86$.

Green, S.D., Harty, C.F., Elmualim, A.A., Larsen, G.D. and Kao, C-C., 2008. On the discourse of construction competitiveness. Building Research \& Information, 36(5), 426-435.

Guérard, S., Langley, A. and Seidl, D., 2013. Rethinking the concept of performance in strategy research: Towards a performativity perspective.M@n@gement, 16(5), 566-578.

Harty, C.F., 2005. Innovation in construction: A sociology of technology approach. Building Research \& Information, 33(6), 512-522.

Hermanns, H., 2002. Interviewing as an activity. In: U. Flick, E. Von Kardoff and I. Steinke ed. A companion to qualitative research. London: Sage Publications, 209-213.

Humphreys, M. and Brown, A.D. 2002. Narratives of organizational identity and identification: A case study of hegemony and resistance. Organization Studies, 23(3), 421-447.

HM Government, 2013. Industrial Strategy: Construction 2025. London: HM Government. 
Hobday, M., 2000. The project-based organisation: An ideal form for managing complex products and systems? Research Policy, 29(7-8), 871-893.

Holloway, W. and Jefferson, T., 2008. The free association narrative interview method. In: L.M. Given ed. The Sage Encyclopaedia of qualitative research methods. Sevenoaks: Sage Publications, 296-315.

Hopf, C., 2004. Qualitative interviews: An overview. In: U. Flick, E. Von Kardorff and I. Steinke ed. A companion to qualitative research. London: Sage Publications, 203-208.

Ibarra, H. and Barbulescu, R., 2010. Identity as narrative: prevalence, effectiveness, and consequences of narrative identity work in macro work role transition. Academy of Management Review, 35(1), 135-154.

Institution of Civil Engineers (ICE), 2015. Innovation: Stepping up the industry. London: Institution of Civil Engineers.

Järventie-Thesleff, R. and Tienari, J., 2016. Roles as mediators in identity work. Organization Studies, 37(2), 237-265.

Kanjanabootra, S. and Corbitt, B., 2016. Reproducing knowledge in construction expertise: a reflexive theory, critical approach, Construction Management and Economics, 34(7-8), $561-577$.

Leiringer, R. and Cardellino, P., 2008. Tales of the expected: Investigating the rhetorical strategies of innovation champions. Construction Management and Economics, 26(10), 1043-1054.

Loosemore, M. and Richard, J., 2015. Valuing innovation in construction and infrastructure: Getting clients past a lowest price mentality. Engineering, Construction and Architectural Management, 22(1), 38-53.

Löwstedt, M. and Räisänen, C., 2012. 'Playing back-spin balls': Narrating organizational change in construction. Construction Management and Economics, 30(9), 795-806. 
Löwstedt, M. and Räisänen, C., 2014. Social identity in construction: Enactments and outcomes. Construction Management and Economics, 32(11), 1093-1105.

Maclean, M., Harvey, C. and Chia, R., 2012. Sensemaking, storytelling and the legitimization of elite business careers. Human Relations, 65(1), 17-40.

Manning, P.K. and Cullum-Swan, B., 1994. Narrative, content and semiotic analysis. In: N.K. Denzin Y.S. and Lincoln ed. Handbook of Qualitative Research. Thousand Oaks: Sage Publications, 463-477.

Mishler, E.G., 1991. Research interviewing: Context and narrative. Harvard: Harvard University Press.

Nayak A. and Chia, R., 2011. Thinking becoming and emergence: process philosophy and organization studies. Philosophy and Organization Theory, 32, 281-209.

Ness, K., 2010. The discourse of 'respect for people' in UK construction. Construction Management and Economics, 28(5), 481-493.

Ness, K. and Green, S.D., 2012. Human resource management in the construction context: disappearing workers in the UK. In: A. Dainty and M. Loosemore ed. Human resource management in construction: Critical perspectives. Abingdon: Routledge, 18-50.

Rantakari, A. and Vaara, E., 2017. Narratives and processuality. In: A. Langley and H. Tsoukas ed. The Sage Handbook of process organisation studies. London: Sage Publications, 271-285.

Rescher, N., 1996. Process metaphysics. NY: SUNY Press.

Rhodes, C. and Brown, A.D., 2005. Narrative, organizations and research. International Journal of Management Reviews, 7(3), 167-188.

Rogers, E.M., 1995. Diffusion of innovation. NY: The Free Press.

Saunders, M., Lewis, P. and Thornhill, A., 2012. Research methods for business students. London: Pearson. 
Schumpeter, J.A., 1976. Capitalism, socialism and democracy (eds). London: George Allen and Unwin. [First published 1942].

Seidel, V.P. and O’Mahony, S., 2014. Managing the repertoire: Stories, metaphors, prototypes and concept coherence in product innovation. Organization Science, 25(3), 691-712.

Sergeeva, N., 2014. Understanding of labelling and sustaining of innovation in construction: A sensemaking perspective. Engineering Project Organization Journal, 4(1), 31-43.

Sexton, M. and Barrett, P., 2005. Performance-based building and innovation: Balancing client and industry needs. Building Research \& Information, 33(2), 142-148.

Sherratt, F., 2014. Exploring 'zero-target' safety programmes in the UK construction industry. Construction Management and Economics, 32(7-8), 737-748.

Sherratt, F., Farrell, P. and Noble, R., 2013. UK construction site safety: Discourses of enforcement and engagement. Construction Management and Economics, 31(6), 623635.

Shibeika, A., and Harty, C., 2015. Diffusion of digital innovation in construction: A case study of a UK engineering firm. Construction Management and Economics, 33(5-6), 453466.

Sims, D., 2003. Between the millstones: A narrative account of the vulnerability of middle managers' storying. Human Relations, 56(10), 1195-1211.

Smiley, J-P., 2016. Exploring policy discourses in the UK construction sector: An interpretive analysis. Thesis (PhD). Loughborough University.

Sveningsson, S. and Alvesson, M., 2003. Managing managerial identities. Human Relations, 56(10), 1163-1193.

Thomas, R. and Davies, A., 2005. Theorising the micro-politics of resistance: Discourses of change and professional identities in the UK public services. Organization Studies, 26(5), 683-706. 
Tsoukas, H. and Chia, R., 2002. On organizational becoming: rethinking organizational change. Organization Science, 13(5), 567-582.

Ybema, S., Keenoy, T., Oswick, C., Beverungen, A., Ellis, N. and Sabelis, I., 2009. Articulating identities. Human Relations, 62(3), 299-322.

Vaara, E., Sonenshein, S. and Boje, D., 2016. Sources of stability and change in organizations: Approaches and directions for future research. The Academy of Management Annals, 10(1), 495-560.

Vaara, E. and Tienari, J., 2011. On the narrative construction of multinational corporations: An antenarrative analysis of legitimation and resistance in a cross-border merger. Organization Science, 22(2), 370-390.

Van Maanen, J., Sørensen, J.B. and Mitchell, T.R., 2007. The interplay between theory and method. Academy of Management Review, 32(4), 1145-1154.

Weick, K.E., 1979. The social psychology of organizing. Reading, MA: Addison-Wesley.

Whyte, J. and Sexton, M., 2011. Motivations for innovation in the built environment: New directions for research. Building Research \& Information, 39(5), 473-482.

Winch, G.M., 1998. Zephyrs of creative destruction: Understanding the management of innovation in construction. Building Research \& Information, 26(4), 268-279.

Winch, G.M., 2014. Three domains of project organising. International Journal of Project Management, 32(5), 721-731.

Table 1 Interviewees' characteristics

\begin{tabular}{|l|l|l|}
\hline Pseudonym & Job title & Nature of enterprise \\
\hline
\end{tabular}




\begin{tabular}{|c|c|c|}
\hline Calvin & Chief Executive & $\begin{array}{l}\text { Global provider of professional technical and } \\
\text { management services; c. } 2,500 \text { employees }\end{array}$ \\
\hline Albert & Senior Manager & $\begin{array}{l}\text { Global project development and construction group; } \\
\text { c. } 43,000 \text { employees }\end{array}$ \\
\hline Charles & $\begin{array}{l}\text { Innovation } \\
\text { Knowledge } \\
\text { Manager }\end{array}$ & $\begin{array}{l}\text { UK technology-based construction and engineering } \\
\text { company providing a broad range of innovative } \\
\text { services; c. } 4,000 \text { employees }\end{array}$ \\
\hline Samuel & $\begin{array}{l}\text { Business } \\
\text { Improvement } \\
\text { Manager }\end{array}$ & $\begin{array}{l}\text { UK construction company providing housebuilding } \\
\text { and regeneration services; c. } 6,000 \text { employees }\end{array}$ \\
\hline Alexander & Chief Executive & $\begin{array}{l}\text { Social enterprise working with local people and } \\
\text { partners to provide rented homes, shared ownership } \\
\text { and new homes for local people; } \\
\text { c. } 250 \text { employees }\end{array}$ \\
\hline Martin & Senior Manager & $\begin{array}{l}\text { International management consultancy and } \\
\text { construction company that provides development, } \\
\text { consultancy, construction and operation services; c. } \\
\text { 4,500 employees }\end{array}$ \\
\hline Thomas & Chief Executive & $\begin{array}{l}\text { Design, engineering and project management } \\
\text { consultancy; c. } 18,000 \text { employees }\end{array}$ \\
\hline Derek & $\begin{array}{l}\text { Business } \\
\text { Development } \\
\text { Manager }\end{array}$ & $\begin{array}{l}\text { International infrastructure group with capabilities in } \\
\text { construction services, support services and } \\
\text { infrastructure investments; c. } 30,000 \text { employees }\end{array}$ \\
\hline
\end{tabular}




\begin{tabular}{|c|c|c|}
\hline Paul & Design Manager & $\begin{array}{l}\text { International infrastructure group with capabilities in } \\
\text { construction services, support services and } \\
\text { infrastructure investments; c. } 30,000 \text { employees }\end{array}$ \\
\hline Ralph & Senior Manager & $\begin{array}{l}\text { A global provider of professional technical and } \\
\text { management services; c. } 2,500 \text { employees }\end{array}$ \\
\hline Philip & Chief Executive & $\begin{array}{l}\text { Multinational construction and facilities company; } \\
\text { c. } 180,000 \text { employees }\end{array}$ \\
\hline Jeremy & $\begin{array}{l}\text { Strategic business } \\
\text { manager }\end{array}$ & $\begin{array}{l}\text { Software engineering company providing analysis } \\
\text { and design, detailing and project communication; } \\
\text { c. } 500 \text { employees }\end{array}$ \\
\hline Neal & $\begin{array}{l}\text { Regional } \\
\text { Managing director }\end{array}$ & $\begin{array}{l}\text { Construction company with end-to-end project life- } \\
\text { cycle expertise to deliver infrastructure projects; } \\
\text { c. } 250 \text { employees }\end{array}$ \\
\hline Oscar & Senior Manager & $\begin{array}{l}\text { A global provider of professional technical and } \\
\text { management services; c. } 2,500 \text { employees }\end{array}$ \\
\hline Victor & $\begin{array}{l}\text { Commercial } \\
\text { director }\end{array}$ & $\begin{array}{l}\text { A manufacturer of plastic piping systems, for use in } \\
\text { the residential, commercial, civils and infrastructure } \\
\text { sectors; c. 3,000 employees }\end{array}$ \\
\hline William & $\begin{array}{l}\text { Director and } \\
\text { Proprietor }\end{array}$ & $\begin{array}{l}\text { Architecture, planning and construction } \\
\text { management services provider; c. } 250 \text { employees }\end{array}$ \\
\hline Chris & Chief Executive & $\begin{array}{l}\text { Construction project management consultancy } \\
\text { providing commercial, procurement and marketing } \\
\text { services; c. } 250 \text { employees }\end{array}$ \\
\hline
\end{tabular}




\begin{tabular}{|c|c|c|}
\hline Warren & $\begin{array}{l}\text { Managing } \\
\text { Director }\end{array}$ & $\begin{array}{l}\text { Sub-contractor offering lining, ceilings and special } \\
\text { internal fit-out to main contractors, owner clients } \\
\text { and architects; c. } 500 \text { employees }\end{array}$ \\
\hline Quinn & $\begin{array}{l}\text { Commercial } \\
\text { Director }\end{array}$ & $\begin{array}{l}\text { Residential property development company in UK; } \\
\text { c. } 6,000 \text { employees }\end{array}$ \\
\hline Rodney & Chief Executive & $\begin{array}{l}\text { Residential property development company in UK; } \\
\text { c. } 6,000 \text { employees }\end{array}$ \\
\hline David & $\begin{array}{l}\text { Managing } \\
\text { Director }\end{array}$ & $\begin{array}{l}\text { Multinational construction, property and } \\
\text { infrastructure company; c. 11,000 employees }\end{array}$ \\
\hline Sebastian & Senior Manager & $\begin{array}{l}\text { Multinational professional services firm providing } \\
\text { engineering, design, planning, project management } \\
\text { and consulting services; c. } 13,000 \text { employees }\end{array}$ \\
\hline Marshall & Chief Executive & $\begin{array}{l}\text { Multinational professional services firm providing } \\
\text { engineering, design, planning, project management } \\
\text { and consulting services; c. } 13,000 \text { employees }\end{array}$ \\
\hline Elizabeth & Chief Executive & $\begin{array}{l}\text { International construction engineering company; c. } \\
15,000 \text { employees }\end{array}$ \\
\hline Brian & $\begin{array}{l}\text { Regional } \\
\text { Managing } \\
\text { Director }\end{array}$ & $\begin{array}{l}\text { Global engineering, construction, and operations } \\
\text { organisation ; c. } 26,000 \text { employees }\end{array}$ \\
\hline Chris & Chief Executive & $\begin{array}{l}\text { Multinational construction and development } \\
\text { company; c. 43,000 employees }\end{array}$ \\
\hline Kevin & $\begin{array}{l}\text { Head of } \\
\text { Innovation }\end{array}$ & $\begin{array}{l}\text { Multinational construction and development } \\
\text { company; c. 30,000 employees }\end{array}$ \\
\hline
\end{tabular}




\begin{tabular}{|l|l|l|}
\hline George & Chief Executive & $\begin{array}{l}\text { Multinational construction and development } \\
\text { company; c. 30,000 employees }\end{array}$ \\
\hline Oliver & Chief Executive & $\begin{array}{l}\text { Construction provider of engineering solutions for } \\
\text { rail, roads, water and land remediation; c. 5,000 } \\
\text { employees }\end{array}$ \\
\hline Stephen & R\&D Manager & $\begin{array}{l}\text { International infrastructure group with capabilities in } \\
\text { construction services, support services and } \\
\text { infrastructure investments; c. 30,000 employees }\end{array}$ \\
\hline Richard & Head of & $\begin{array}{l}\text { Multinational company involved in design, } \\
\text { construction, financing, operation and maintenance } \\
\text { of transport, urban and services infrastructure; c. } \\
75,000 \text { employees }\end{array}$ \\
\hline Matthew & R\&D Manager & $\begin{array}{l}\text { UK construction company providing housebuilding } \\
\text { and regeneration services; c. 6,000 employees }\end{array}$ \\
\hline
\end{tabular}

